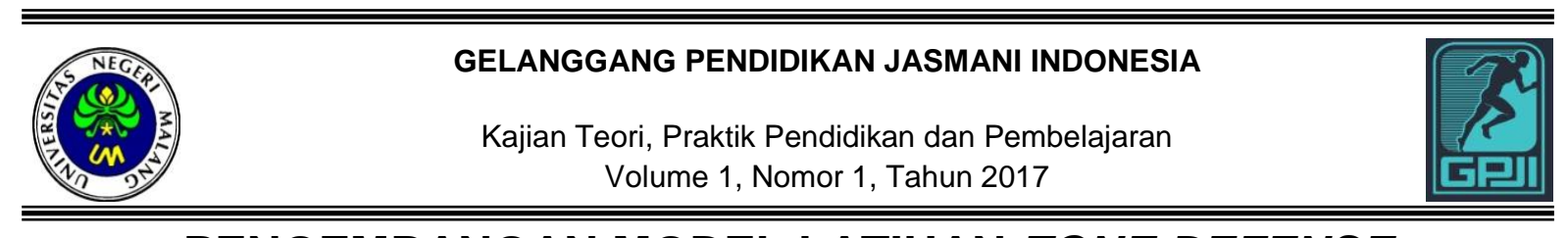

\title{
PENGEMBANGAN MODEL LATIHAN ZONE DEFENSE MENGGUNAKAN VIDEO PADA KEGIATAN EKSTRAKURIKULER BOLABASKET DI CHARIS NATIONAL ACADEMY MALANG
}

\author{
Ratna Nathania N.U \\ Siti Nurrochmah \\ Febrita Paulina Heynoek \\ Fakultas IImu Keolahragaan Universitas Negeri Malang \\ Email: ivon.nathania@ymail.com
}

\begin{abstract}
In the basketball extracurricular program, the participants will be taught about technic and strategy of playing basketball. The result of need analysis shows that: (1) participants found that it is difficult to learn about defense zone, (2) participants need variations of defense zone practice which is easily to be understood through video. This research aimed to develop zone defense practice model that is packaged using video media according to the characteristics of participants. This study uses a conceptual model based on the operational theory or principles validated. The results of data analysis of 10 participants in the small group in the extracurricular activities is $74,5 \%$ and the results of data analysis of 30 participants in the big group is $78,6 \%$.
\end{abstract}

Keywords: Basketball, Zone Defense Practice Model, Media, Video

\begin{abstract}
Abstrak: Pada kegiatan ekstrakurikuler bolabasket peserta dilatih teknik dan taktik bermain bolabasket. Dari hasil analisis kebutuhan ditemukan masalah yang muncul antara lain: (1) peserta mengalami kesulitan dalam menerima materi latihan zone defense, (2) peserta sangat membutuhkan model latihan zone defense yang variatif dan mudah dipahami melalui media video. Penelitian ini bertujuan mengembangkan model latihan zone defense yang dikemas dalam bentuk video sesuai karakteristik peserta kegiatan ekstrakurikuler. Penelitian ini menggunakan model konseptual berdasarkan operasional teori atau prinsip-prinsip yang tervalidasi. Berdasarkan hasil uji coba kelompok kecil dari 10 peserta diperoleh $74,5 \%$ dan ui coba kelompok besar dari 30 peserta diperoleh $78,6 \%$.
\end{abstract}

Kata Kunci: Bolabasket, Model Latihan Zone Defense, Media, Video

Di dalam dunia pendidikan, kegiatan ekstrakurikuler yaitu kegiatan yang diselenggarakan khusus oleh pihak sekolah untuk mengembangkan kemampuan peserta didik di luar jam sekolah. Menurut Prihatin (2011:180), kegiatan ekstrakurikuler adalah kegiatan pendidikan di luar mata pelajaran dan pelayanan konseling untuk membantu pengembangan peserta didik sesuai dengan kebutuhan, potensi, bakat dan minat mereka melalui kegiatan yang secara khusus diselenggarakan oleh pendidik atau tenaga kependidikan yang berkemampuan dan berkewenangan di sekolah atau madrasah. Hal ini didukung oleh Permendikbud no. 62 tahun 2014, menjelaskan definisi kegiatan ekstrakurikuler adalah kegiatan yang dilakukan oleh peserta didik di luar jam belajar kegiatan intrakurikuler dan kegiatan kokurikuler, dibawah bimbingan dan pengawasan satuan pendidikan bertujuan untuk mengembangkan potensi, bakat, minat, kemampuan, kepribadian, kerjasama, dan kemandirian peserta didik secara optimal untuk mendukung pencapaian tujuan pendidikan. Wahjosumidjo dalam Kompri (2015:225) menjelaskan bahwa kegiatan ekstrakurikuler adalah kegiatan-kegiatan peserta didik di luar jam pelajaran yang dilaksanakan di sekolah atau di luar sekolah. Salah satu tujuan ekstrakurikuler dikemukakan oleh Kompri (2015:227) yaitu kegiatan 
Ratna Nathania N U, Pengembangan Model Latihan Zone Defense Menggunakan Video Pada Kegiatan Ekstrakurikuler Bolabasket di Charis National Academy Malang

ekstrakurikuler harus dapat meningkatkan kemampuan kognitif, afektif, dan psikomotorik peserta didik.

Berdasarkan pendapat beberapa ahli, dapat disimpulkan bahwa kegiatan ekstrakurikuler adalah kegiatan di luar jam pelajaran yang dilaksanakan disekolah atau di luar sekolah untuk mengembangkan potensi, bakat, dan minat peserta didik sesuai dengan kebutuhannya.

Bentuk kegiatan ekstrakurikuler berupa aktivitas olahraga dan non-olahraga yang sifatnya tidak mengikat, jadi peserta didik bebas untuk memilih setiap kegiatan ekstrakurikuler sesuai dengan kemampuan mereka. Salah satu aktivitas olahraga yang diminati oleh peserta didik yaitu olahraga bolabasket.

Federation International De Basketball atau FIBA adalah induk organisasi bolabasket di dunia. Menurut FIBA (2012:1), bolabasket dimainkan oleh dua tim yang masing-masing terdiri dari lima pemain. Tujuan dari masing-masing tim adalah untuk menghasilkan angka ke keranjang lawan dan berusaha mencegah tim lawan menghasilkan angka. Permainan bolabasket merupakan salah satu cabang olahraga permainan yang tumbuh dan berkembang sangat pesat di Indonesia, terbukti pada tahun 2003 diselenggarakan kompetisi profesional Indonesia Basketball League (IBL), namun pada tahun 2010 berganti nama menjadi National Basketball League (NBL), pada tahun 2010 juga diselenggarakan Development Basketball League (DBL) yang merupakan liga basket pelajar terbesar di Indonesia.

Permainan bolabasket merupakan permainan invasi yaitu permainan tim dimana skor diperoleh jika pemain secara beregu mampu memanipulasi bola atau proyektil sejenis untuk dimasukkan ke gawang lawan atau daerah tertentu lebih banyak dan mampu mempertahankan gawang atau daerahnya sendiri (Pujianto, 2014:83). Dalam permainan bolabasket terdapat macam-macam teknik dasar yaitu passing, catcing, dribbling, shooting, footwork, pivot. Setelah penguasaan teknik dasar terpenuhi baru kemudian pemain dilatih keterampilan menyerang dan bertahan. Ahmadi (2007:13) berpendapat bahwa untuk memiliki suatu tim bolabasket yang handal ada tiga faktor utama yang harus dipenuhi yaitu: (1) penguasaan teknik dasar; (2) ketahanan fisik; (3) kerjasama. Akan tetapi dari beberapa faktor tersebut yang menjadi materi utama dalam penelitian ini adalah strategi khususnya pola pertahanan daerah (zone defense).

Menurut Budiwanto (2011:39) terdapat beberapa faktor yang dapat menentukan keberhasilan atlet atau regu antara lain: (1) kemampuan fisik, teknik, dan mental atlet; (2) pemahaman teoritis dan menguasai bentuk pola-pola, taktik, dan stategi; (3) kemampuan kognitif atlet; (4) kemampuan beradaptasi terhadap keadaan lingkungan dilapangan; (5) pemahaman peraturan permainan dan pertandingan.

Dalam permainan bolabasket terdapat dua pola pertahanan yaitu pertahanan daerah (zone defense) dan pertahanan satu lawan satu (man to man defense) (Husdarta \& Maryani, 2010:97). Taktik pertahanan dalam bermain bolabasket sangatlah penting. Hal ini sejalan dengan pendapat Oliver (2007:76) bahwa setiap pemain bolabasket akan menghabiskan rata-rata $50 \%$ waktu pertandingan untuk bertahan dan melindungi ring basket. Hal ini didukung oleh pendapat Mukholid (2007:14) bahwa pemain bolabasket harus menguasai strategi dan taktik. Dalam strategi pelatih lebih dominan peranannya daripada pemain, sedangkan dalam taktik pemain sebagai pelaku utama dalam pertandingan agar dapat menghasilkan angka dan menghalau lawan untuk menghasilkan angka.

Pertahanan atau defense bolabasket adalah suatu usaha yang dijalankan oleh tim bertahan dalam rangka menghalau serangan lawan (Husdarta \& Maryani, 2010:97). Teknik-teknik dalam melakukan pertahanan dalam bermain bolabasket meliputi teknik memperhatikan dan berusaha mempengaruhi lawan, menghentikan operan bola yang efektif, menghentikan dribbling serta merebut bola kembali, mencegah dan menghalangi pemain lawan yang sedang melakukan tembakan (Mukholid, 2007:75).

Unsur-unsur penting bagi pemain bolabasket dalam melakukan pertahanan antara lain: (1) bergerak menyamping; (2) mengubah arah; (3) menjaga pemain post; (4) menghalau bola dan memotong umpan (Oliver, 2007:78-80). Gilang (2007:134) berpendapat antara lain: (1) sikap jaga; (2) olah kaki untuk memenangkan langkah da- 
lam bertahan; (3) dasar-dasar umum dalam penjagaan; (4) posisi jaga dan pem-bagian daerah; (5) penjagaan terhadap situasisituasi khusus, (6) pertahanan berkawan.

Berdasarkan pendapat beberapa ahli tersebut diatas, dapat disimpulkan bahwa untuk dapat melakukan pertahanan (defense) yang baik, pemain harus mempunyai kemampuan bertahan yang baik. Keterampilan bertahan yang dimiliki oleh pemain bolabasket dapat diterapkan pada salah satu pola pertahanan bolabasket yaitu pertahanan daerah (zone defense).

Pertahanan daerah (zone defense) merupakan salah satu strategi umum yang diterapkan dalam permainan bolabasket. Menurut Zheng (2010:19), pola pertahanan daerah (zone defense) ini berbeda dengan pola man to man defense yang menjaga pemain tertentu, tetapi zone defense mempunyai tugas dominan menjaga daerah pertahanan. Jenis zone defense menurut Ahmadi (2007:52) yaitu 2-1-2, 2-3, 3-2, 1-22 , 1-3-1, 2-2-1. Setiap pola pertahanan dalam bolabasket mempunyai kekuatan dan kelemahan masing-masing.

Menurut Oliver (2007:50-51), kekuatan zone defense antara lain: (1) sangat baik untuk melawan tim yang lemah dalam mengontrol bola; (2) sangat efektif untuk melawan penyerang pivot yang berbahaya; (3) sangat efektif untuk melawan tim yang harus memasang adegan polanya terlebih dahulu; (4) sangat efektif untuk melawan regu yang bermain dengan taktik cutting; (5) baik digunakan untuk pemain pemula. Kelemahan zone defense antara lain: (1) pertahanan mudah ditembus oleh lawan apabila lawah memiliki kemampuan shooting jarak jauh; (2) kemampuan dasar pertahanan individu kurang baik; (3) penyerang mudah membekukan permainan jika mereka berada pada pihak yang memimpin poin.

Passig (2014:23) berpendapat bahwa penerapan zone defense didasari oleh beberapa faktor antara lain: (1) zone defense mudah dipelajari daripada man to man defense; (2) banyak macam pola zone defense yang dapat digunakan tergantung situasi saat bertanding/dilapangan; (3) zone defense dapat mengatur tempo/alur permainan tim. Salah satu pola zone defense yang dikembangkan dalam pene-litian dan pengembangan ini yaitu jenis pola zone defense 2-1-2 dan 1-2-2. Zone defense 2-12 merupakan pola pertahanan yang sangat kuat di daerah pivot dan daerah rebound, sedangkan pola 1-2-2 merupakan pola pertahanan yang cukup kuat untuk melawan penembak dari jarak jauh dan juga lebih memberikan perlindungan di daerah pivot (Oliver 2007:52).

Berdasarkan pendapat ahli tersebut diatas, dapat disimpulkan bahwa terdapat macam-macam jenis pola pertahanan daerah (zone defense) yaitu 2-1-2, 2-3, 3-2, 1-2-2, dan 2-2-1 serta terdapat kelemahan dan kekuatan pada pola zone defense bolabasket. Dalam pengembangan model latihan zone defense yang sesuai dengan karakteristik perserta kegiatan ekstrakurikuler bolabasket di Charis National Academy Malang untuk mengatasi permasalahan yang muncul peneliti mengembangkan 4 jenis latihan zone defense. Berikut adalah 4 jenis latihan zone defense yang dikembangkan: (1) drill footwork defense terdiri atas 4 model latihan; (2) drill fundamental defense terdiri atas 3 model latihan; (3) drill moving defense terdiri atas 6 model latihan; (4) drill team defense terdiri atas 3 model. latihan.

Berdasarkan hasil analisis kebutuhan yang diberikan kepada pelatih ekstrakurikuler bolabasket di Charis National Academy Malang diperoleh data bahwa pelatih mengalami kesulitan dalam memberikan latihan karena peserta kurang memahami drill yang diberikan, acuan pelatih dalam memberikan pelatihan yaitu pengalaman yang didapatkan pelatih, pelatih membutuhkan media yang efektif dan variatif untuk dapat membantu peserta dalam memahami materi yang akan disampaikan.

Berdasarkan hasil analisis kebutuhan dari hasil kuisioner dari 30 peserta kegiatan ekstrakurikuler bolabasket di Charis National Academy Malang diperoleh (1) $60 \%$ menyatakan bahwa peserta mengalami kesulitan dalam menerima materi latihan zone defense; (2) $66,7 \%$ menyatakan bahwa kurang banyaknya model latihan zone defense yang diberikan oleh pelatih; (3) $56,67 \%$ menyatakan bahwa sangat setuju apabila diberikan model latihan zone defense; (4) 73,4\% menyatakan bahwa sangat setuju apabila model latihan zone defense dikemas menggunakan video dan diberikan 
Ratna Nathania N U, Pengembangan Model Latihan Zone Defense Menggunakan Video Pada Kegiatan Ekstrakurikuler Bolabasket di Charis National Academy Malang

pada peserta kegiatan ekstrakurikuler bolabasket di Charis National Academy Malang.

Beberapa penelitian dan pengembangan terdahulu dalam olahraga yang relevan dengan penelitian dan pengembangan ini adalah (1) Hendra M. Kukuh S. 2008. Pengembangan Model Latihan Zone Defense/Bertahan dalam Kegiatan Ekstrakurikuler Bolabasket di SMA Islam Kepanjen Kabupaten Malang. Pada penelitiannya, saudara Kukuh mengem-bangkan 13 model latihan pola zone defense yang dikemas dalam media cetak berupa buku pedoman, (2) Metalian, Alfredo, Jerry M. 2015. Pengembangan Model Latihan Man to Man Defense Bolabasket Menggunakan Modifikasi Permainan Gobak Sodor di Ekstrakurikuler SMP Laboratorium UM Malang. Berdasarkan hasil penelitian terdahulu yang telah dipaparkan, peneliti menjadikan hasil penelitian tersebut sebagai refrensi dalam mengembangkan produk ini.

Untuk dapat memahami strategi dan taktik yang diberikan oleh pelatih saat di lapangan, pelatih memberikan latihan yang baik dan benar sesuai dengan prinsip-prinsip latihan untuk mencapai hasil latihan yang optimal, membentuk tim yang baik, dan mengurangi resiko cedera yang dialami oleh peserta latihan pada saat latihan/bertanding.

Menurut Irianto (2009:1), latihan adalah proses sistematis untuk menyempurnakan kualitas kinerja peserta latihan berupa kebugaran keterampilan dan kapasitas energi dengan memperhatikan aspek pendidikan menggunakan pendekatan ilmiah. Latihan menurut Budiwanto (2012:16) adalah proses melakukan kegiatan olahraga yang dilakukan berdasarkan program latihan yang disusun secara sistematis. Adapun tujuan latihan yaitu meningkatkan kapasitas kerja peserta latihan, keefektifan, dan kualitas psikologi untuk meningkatkan performa peserta latihan (Bompa, 2009:30). Hal ini didukung oleh pendapat Sukadiyanto (2011:9) bahwa tujuan latihan yaitu meningkatkan kualitas fisik dasar secara umum dan menyeluruh, mengembangkan dan meningkatkan potensi fisik yang khusus, menambah dan menyempurnakan teknik, me-ngembangkan dan menyempurnakan strategi, taktik, dan pola bermain, dan meningkatkan kualitas dan kemampuan psikis olahraga dalam bertanding.

Berdasarkan pendapat ahli yang telah diuraikan tersebut diatas, dapat disimpulkan bahwa latihan adalah kegiatan olahraga yang dilakukan secara sistematis, terencana, dan terpogram untuk mencapai tujuan latihan itu sendiri. Latihan dalam olahraga berarti berbicara tentang kemampuan gerak individu yang dilatih secara berulang-ulang untuk mencapai keotomatisasian gerak secara kompleks.

Indahwati dan Tohirun (2015:2), kemampuan motorik adalah suatu proses pembentukan sistematika kognitif tentang gerak pada diri setiap peserta latihan yang kemudian diaplikasikan dalam psikomotorik, mulai dari tingkat keterampilan gerak yang sederhana hingga keterampilan gerak yang kompleks untuk mencapai otomatisasi gerak. Dwijowinoto (1993:196) juga berpendapat bahwa penampilan olahraga yang berhasil tergantung pada pencapaian kemampuan pada tiap-tiap ranah tingkah laku, bukan hanya kemampuan gerak yang harus ditampilkan secara efisien (psikomotorik) tetapi harus juga memiliki pengetahuan yang sempurna tentang kognitif dan afektif.

Pada ranah kognitif menuntut peserta latihan menggunakan kemampuan intelektual untuk mempelajari peraturan, perkembangan strategi permainan, merencanakan keterampilan gerak dan penggunaan informasi yang telah dipelajari secara efisien. Sedangkan pada ranah psikomotorik berkaitan dengan penerimaan informasi perseptual dan kemampuan untuk menerima respon gerak yang menghasilkan gerak mulai dari kegiatan refleks yang tidak disengaja sampai penampilan keterampilan olahraga yang terpadu dengan baik. Oleh karena itu, dalam kegiatan ekstrakurikuler olahraga, pelatih harus mampu memahami karakteristik perkembangan peserta latihan dan mampu memberikan tugas ketrampilan gerak sesuai dengan perkembangan peserta latihan.

Dalam pemberian latihan kepada peserta latihan, pelatih harus memperhatikan prinsip-prinsip latihan. Menurut Bompa (2009:38) prinsip-prinsip latihan merupakan bagian dari seluruh konsep dan tidak dapat dilihat secara sempit. Hal ini sejalan dengan pendapat Sukadiyanto (2011:13) bahwa dalam satu kali tatap muka, seluruh prinsip latihan dapat diterapkan secara bersamaan dan saling mendukung. Apabila ada prinsip latihan yang tidak 
diterapkan, maka akan berpengaruh terhadap keadaan fisik dan psikis peserta latihan. Dengan memahami prinsip-prinsip latihan akan mendukung upaya dalam meningkatkan kualitas suatu latihan dan menghindarkan peserta latihan dari cedera selama dalam proses latihan.

Dapat disimpulkan dari pendapat ahli tersebut bahwa dengan memperhatikan prinsip-prinsip latihan dalam pemberian latihan maka dapat mengurangi resiko cedera yang dialami oleh peserta latihan. Budiwanto (2012:16) berpendapat bahwa prinsip-prinsip latihan meliputi: (1) prinsip beban lebih; (2) prinsip spesialisasi; (3) prinsip perorangan; (4) prinsip variasi; (5) prinsip beban meningkat bertahap; (6) prinsip perkembangan multirateral; (7) prinsip pulih asal; (8) prinsip kembali asal; (9) prinsip menghindari beban latihan berlebih; (10) prinsip melampaui batas; (11) prinsip aktif partisipasi; (12) prinsip proses latihan menggunakan model; (13) prinsip pemanasan dan pendinginan.

Dari pendapat ahli tersebut dapat disimpulkan bahwa prinsip variasi adalah salah satu dari beberapa prinsip-prinsip latihan yang harus diberikan kepada peserta latihan untuk mengatasi kebosanan peserta latihan saat latihan. Hal ini sejalan dengan pendapat Irianto (2009:13) bahwa variasi perlu diberikan karena model dan metode latihan yang monoton mengakibatkan kebosanan sehingga sasaran latihan tidak dapat dicapai, untuk itu perlu dirancang berbagai model dan metode latihan yang beranekaragam, dengan tetap mengacu pada sasaran latihan. Prinsip latihan variasi dapat berupa variasi tempat, alat yang digunakan ataupun media penyampaian materi.

Sasaran latihan pada penelitian ini adalah faktor taktik. Irianto (2009:17) berpendapat bahwa latihan taktik adalah siasat yang digunakan untuk mencari kemenangan secara sportif pada saat bertanding yang dapat menggunakan jenis taktik perorangan, beregu, tim, taktik menyerang, taktik bertahan, dan sasaran latihan taktik adalah mengembangkan pola pikir bertanding. Sehubungan dengan penelitian dan pengembangan yang dilakukan, peneliti mengembangkan model latihan zone defense yang dikemas menggunakan video sebagai topik penelitian. Hal ini dipilih sesuai analisis kebutuhan peserta dan pelatih kegiatan ekstrakurikuler bolabasket yang membutuhkan variasi model latihan zone defense yang dikemas menggunakan video untuk mengatasi kebosanan dan membantu peserta latihan dalam proses pemahaman materi.

Menurut Lamatenggo dan Uno (2010:121) media merupakan alat komunikasi yang digunakan untuk membawa suatu informasi dari suatu sumber kepada penerima. Sikhabuden (2011:3) berpendapat bahwa media adalah suatu alat atau saran atau perangkat dalam kegiatan komunikasi antara komunikator dan komunikan. Hal ini sejalan dengan pendapat Rusman, dkk. (2013:169) bahwa media merupakan wahana penyalur informasi belajar atau penyalur pesan.

Berdasarkan pendapat ahli tentang media, dapat disimpulkan bahwa media merupakan alat komunikasi antara sumber pesan dan penerima pesan. Keberadaan media dalam proses pembelajaran/pelatihan sangat penting untuk menunjang kelancaran pelaksanaan pelatihan.

Riyana dan Susilana (2009:15) menjelaskan media pelatihan sebagai salah satu komponen yang tidak dapat berdiri sendiri, tetapi saling berhubungan dengan komponen lainnya untuk menciptakan situasi pelatihan yang diharapkan. Menurut Pribadi (2011:88), media pelatihan adalah alat yang digunakan untuk mendukung berlangsungnya proses pelatihan yang efektif, efisien, dan menarik. Hal ini sejalan dengan pendapat Rusman, dkk. (2013:170) bahwa media pelatihan merupakan salah satu komponen proses pelatihan yang memiliki peranan sangat penting dalam menunjang keberhasilan proses pelatihan

Jadi dapat disimpulkan bahwa media pelatihan merupakan alat atau bahan yang digunakan untuk menyampaikan materi atau informasi pelatihan yang bersifat efektif, efisien, dan menarik dalam menunjang keberhasilan proses pelatihan. Adapun fungsi media pelatihan menurut Dwiyogo (2010:230) antara lain: (1) media pelatihan menarik dan memperbesar perhatian peserta latihan terhadap materi yang disajikan; (2) media pelatihan mengatasi perbedaan pengalaman belajar; (3) media pelatihan mem- 
Ratna Nathania N U, Pengembangan Model Latihan Zone Defense Menggunakan Video Pada Kegiatan Ekstrakurikuler Bolabasket di Charis National Academy Malang

bantu memberikan pengalaman belajar yang sulit diperoleh dengan cara yang lain; (4) media pelatihan dapat menumbuhkan kemampuan individu berdasarkan pengalaman dan kondisi nyata; (5) media pelatihan dapat mengatasi sikap pasif peserta latihan; (6) media pelatihan dapat memunculkan gairah belajar; (7) media pelatihan menciptakan interaksi langsung antara peserta latihan dengan lingkungan dan kondisi nyata; (8) media pelatihan dapat mendorong peserta latihan untuk dapat berlatih secara mandiri sesuai dengan kemampuannya. Rowntree dalam Sikhabuden (2011:5) mengemukakan enam fungsi media pelatihan sebagai berikut: (1) membangkitkan motivasi belajar; mengulang materi yang telah dipelajari; (3) menyediakan stimulus belajar/berlatih; (4) meng-aktifkan respon belajar/berlatih; (5) memberikan umpan balik; (6) menggalakkan latihan yang serasi. Hal ini sejalan dengan pendapat Hamalik dalam Rusman, dkk. (2013:172) tentang fungsi media pelatihan antara lain: (1) untuk mewujudkan situasi pelatihan yang efektif; (2) penggunaan media merupakan bagian integral dalam sistem pelatihan; (3) media pelatihan penting dalam mencapai tujuan latihan; (4) mempercepat proses pelatihan; (5) mempertinggi mutu pelatihan.

Berdasarkan pendapat ahli tentang fungsi media yang telah diuraikan diatas, dapat disimpulkan bahwa media pelatihan memiliki fungsi yang sangat penting dalam kegiatan pelatihan untuk menunjang keberhasilan proses pelatihan.

Jayanti (2015:19-20), media pelatihan berdasarkan sifatnya digolongkan sebagai berikut: (1) media auditif, yaitu media yang hanya dapat didengar saja karena hanya terdiri dari unsur suara seperti radio dan rekaman suara; (2) media visual, yaitu media yang hanya dapat dilihat saja tanpa mengandung unsur suara seperti media grafis; dan media audiovisual, yaitu media yang bisa dilihat dan didengar karena mengadung unsur suara dan gambar didalamnya seperti film dan video.

Ditinjau berdasarkan sifatnya, media audiovisual sebagai media pelatihan yang tepat untuk dapat digunakan dalam pembelajaran gerak. Penggunaan media audiovisual ini lebih efektif penggunaannya bila dibandingkan dengan media pesan visual dan media audio. Hal ini sejalan dengan pendapat Hariyanto dan Suyono (2011:49) bahwa gaya belajar peserta didik yaitu terdiri dari gaya belajar visual dan gaya belajar audio. Penelitian yang dilakukan Daryanto dalam Kusumawardhani (2011:4-5) menyatakan bahwa video merupakan suatu medium yang sangat efektif untuk membantu proses pembelajaran, baik itu pembelajaran masal, individual, maupun berkelompok. Salah satu kelebihan video dalam proses pelatihan olahraga yaitu dapat menyajikan gerak lambat dan memberhentikan gambar yang sedang bergerak untuk dapat menganalisis bagian atau proses dari suatu gerakan dan dapat menjelaskan prosedur tertentu (Lamatenggo \& Uno, 2010:135)

Oleh karena untuk mengatasi masalahmasalah kurang mampunya peserta kegiatan dalam memahami materi zone defense, solusi yang tepat adalah melakukan pengkajian melalui penelitian dan pengembangan terhadap model latihan zone defense menggunakan video pada kegiatan ekstrakurikuler bolabasket di Charis National Academy Malang yang sesuai dengan karakteristik peserta kegiatan ekstrakurikuler dan menggunakan media yang efektif, efisien dan menarik untuk meningkatkan motivasi peserta kegiatan ekstrakurikuler.

Dari masalah-masalah yang ada di lapangan, maka peneliti menemukan solusi dari pemecahan masalah tersebut yaitu dengan melakukan penelitian dan pengembangan berjudul "Pengembangan Model Latihan Zone Defense Menggunakan Video Pada Kegiatan Ekstrakurikuler Bolabasket di Charis National Academy Malang"

Penelitian dan pengembangan ini bertujuan untuk mengatasi masalah-masalah yang ada di lapangan yaitu kurang pahamnya peserta kegiatan ekstrakurikuler dalam memahami dan mempraktikkan pola zone defense. Pelatih juga menyatakan bahwa tidak ada media pelatihan yang dapat digunakan untuk dapat menyampaikan materi model latihan zone defense. Pada kenyataannya peserta kegiatan ekstrakurikuler membutuhkan media yang efektif, efisien, dan menarik untuk mempermudah dalam memahami materi model latihan zone defense. 


\section{METODE}

Berdasarkan pada tujuan penelitian dan pengembangan ini yaitu mengembangkan produk berupa video model latihan zone defense bolabasket, maka model penelitian dan pengembangan yang digunakan dalam penelitian ini berupa model konseptual. Model konseptual adalah model pengembangan berdasarkan operasionalisasi teori atau prinsip-prinsip yang telah tervalidasi ke dalam langkah-langkah atau prosedur yang mengarah pada suatu produk sebagai wujud pemecahan masalah (Mukhadis, 2013:98).

Penelitian dan pengembangan ini menggunakan pendekatan problem oriented karena masalah yang diteliti berdasarkan kondisi nyata di lapangan (Mukhadis, 2013:100), artinya bahwa menentukan prioritas masalah yang diteliti berdasarkan kondisi nyata di lapangan dan mendesak untuk dipecahkan, sehingga produk yang dihasilkan dapat secara langsung dimanfaatkan oleh pengguna untuk meningkatkan proses nilai tambah suatu sistem.

Oleh karena menggunakan model konseptual, maka langkah-langkah penelitian dan pengembangan model latihan zone defense menggunakan video pada kegiatan ekstrakurikuler bolabasket di Charis National Academy Malang merujuk pada langkah-langkah penelitian dan pengembangan dari Borg dan Gall (1983:775). Langkah-langkah penelitian dan pengembangan Borg dan Gall (1983:77) meliputi: (1) Penelitian dan pengumpulan data (research and information collecting). Melakukan pengukuran kebutuhan, studi literature, penelitian skala kecil, dan pertimbanganpertimbangan dari segi nilai; (2) perencanaan (planning). Menyusun rencana penelitian meliputi pendefinisian keterampilan, perumusan tujuan, penentuan urutan pengajaran, dan uji coba skala kecil; (3) mengembangkan produk awal (develop preliminary from of product). Penyiapan materi pengajaran, penyusunan buku pegangan, dan perlengkapan evaluasi; (4) uji lapangan permulaan (preliminary field testing). Uji coba di lapangan pada 1 sampai 3 sekolah dengan 6 sampai 12 subjek uji coba (guru); (5) merevisi hasil uji coba (main product revision). Memperbaiki atau menyempurnakan hasil uji coba; (6) uji coba lapangan (main field testing). Melakukan uji coba yang lebih luas pada 5 sampai 15 sekolah dengan 30 sampai dengan 100 subjek uji coba; (7) penyempurnaan produk hasil uji coba (operational product revision). Melakukan revisi produk yang sesuai dengan saran-saran dari hasil lapangan utama; (8) uji coba pelaksanaan lapangan (operational field testing). Dilaksanakan pada 10 sampai 30 sekolah melibatkan 40 sampai 200 subjek. Pengujian dilakukan melalui angket, wawancara, observasi, dan analisis hasilnya; (9) penyempurnaan produk akhir (final product revision). Penyempurnaan didasarkan masukan uji coba lapangan; (10) diseminasi dan implementasi (dissemination and implementation). Melaporkan hasil dalam pertemuan profesional dan dalam jurnal. Bekerja sama dengan penerbit untuk penerbitan. Memonitor penyebaran untuk pengontrol kualitas.

Langkah-langkah penelitian dan pengembangan yang dikemukakan oleh Borg dan Gall bukan merupakan langkah-langkah baku yang harus diikuti semuanya. Ardhana (2002:9) menyatakan setiap peneliti pengembangan memiliki kebutuhan dan kondisi yang berbeda dalam melaksanakan prosedur penelitiannya. Hal ini menjadikan langkah-langkah penelitian dan pengembangan tidak bersifat kaku dan mutlak, namun dapat disesuaikan dengan kebutuhan dan kondisi dalam proses pengembangan.

Oleh karena itu dalam penelitian dan pengembangan model latihan zone defense menggunakan video pada kegiatan ekstrakurikuler bolabasket di Charis National Academy Malang, peneliti tidak menggunakan sepuluh langkah penelitian dan pengembangan yang dijelaskan Borg dan Gall seutuhnya. Penelitian dan pengembangan ini tidak sampai pada tahap: (1) uji lapangan yang melibatkan jumlah subjek/ wilayah yang lebih besar; (2) pene-litian eksperimental melalui penelitian eksperimental; dan (3) tidak sampai pada langkah diseminasi dan implementasi yaitu melaporkan hasil dalam pertemuan ilmiah, akan tetapi peneliti melakukan penelitian dan pengembangan ini sampai pada langkah ke tujuh yaitu penyempurnaan produk hasil uji coba lapangan, dengan kata lain penelitian dan pengembangan menghasilkan prototipe produk berupa model latihan zone defense 
Ratna Nathania N U, Pengembangan Model Latihan Zone Defense Menggunakan Video Pada Kegiatan Ekstrakurikuler Bolabasket di Charis National Academy Malang

menggunakan video sebagai produk yang teruji disamping disesuaikan dengan karakteristik produk yang dikembangkan.

Dari sepuluh langkah penelitian dan pengembangan yang dikemukakan oleh Borg dan Gall (1983:775), peneliti hanya menggunakan tujuh langkah yaitu: (1) penelitian dan pengumpulan data; (2) menyusun rancangan produk; (3) pengembangan produk awal; (4) uji coba (kelompok kecil); (5) revisi produk; (6) uji lapangan (kelompok besar); (7) revisi produk akhir.

Subjek coba pada penelitian dan pengembangan model latihan zone defense menggunakan video ini meliputi subjek ahli dan subjek coba. Masing-masing subjek coba memiliki karakteristik mencakup: (1) subjek ahli: satu ahli kepelatihan, satu ahli permainan bolabasket, satu ahli pelatih, satu ahli manajemen ekstrakurikuler, dan satu ahli media; (2) subjek coba atau calon pengguna produk pada kelompok kecil melibatkan 10 peserta dan pada kelompok besar 30 peserta kegiatan ekstrakurikuler bolabasket di Charis National Academy Malang.

Instrumen pengumpulan data dalam penelitian dan pengembangan model latihan zone defense menggunakan video menggunakan instrument tes dan non-tes meliputi: (1) observasi untuk analisis kebutuhan dalam penelitian dan pengembangan model latihan zone defense menggunakan video pada kegiatan ekstrakurikuler bolabasket di Charis National Academy Malang; (2) kuisioner digunakan memperoleh data pada waktu studi pendahuluan, uji coba (kelompok kecil), uji lapangan (kelompok besar), dan evaluasi ahli; (3) wawancara digunakan untuk memperoleh informasi awal dari pelatih kegiatan ekstrakurikuler bolabasket tentang keterampilan taktik bermain bolabasket pada waktu studi pendahuluan.

Teknik analisis data yang digunakan oleh peneliti untuk memperoleh data pada studi pendahuluan dan evaluasi ahli pada pengembangan model latihan zone defense menggunakan video di Charis National Academy Malang adalah teknik analisis data deskriptif kualitatif dan kuantitatif. Analisis deskriptif kualitatif digunakan untuk menganalisis hasil pengumpulan data dari tinjauan para ahli menggunakan pendekatan kualitatif. Menurut Sugiyono (2013:338-345), dalam menganalisis data untuk penelitian kualititif sebagai berikut: (1) reduksi data. Proses berfikir sensitif yang memerlukan kecerdasan, keluasan, dan kedalaman wawasan yang tinggi; (2) penyajian data. Penyajian data bisa dilakukan dalam bentuk uraian singkat, bagan, hubungan atar kategori, flowchart, dan sejenisnya; (3) penarikan kesimpulan. Kesimpulan yang dikemukakan pada tahap awal harus didukung oleh bukti-bukti yang valid dan konsisten saat peneliti kembali ke lapangan mengumpulkan data. Analisis deskriptif kuantitatif berupa persentase digunakan untuk menganalisis data kuantitatif uji coba (kelompok kecil) dan uji lapangan (kelompok besar) dan uji ahli.

\section{HASIL}

Berdasarkan pengumpulan data melalui hasil analisis kebutuhan, evaluasi ahli dan uji coba produk disajikan dalam bagian ini. Data hasil evaluasi para ahli meliputi saran dan hasil evaluasi 1 orang ahli kepelatihn, 1 orang ahli permainan bolabasket, 1 orang ahli pelatih, 1 orang manajemen ekstrakurikuler, dan 1 orang ahli media. Data hasil uji coba (kelompok kecil) dan uji lapangan (kelompok besar) diperoleh dari jawaban peserta kegiatan ekstrakurikuler sebagai subjek penelitian terhadap instrumen pengumpulan data yang berupa kuisioner.

Data pertama, merupakan data kuantitatif berupa hasil pengisian instrumen evaluasi ahli kepelatihan terkait produk pengembangan model latihan zone defense berdasarkan komponen produk terhadap aspek ketepatan diperoleh persentase sebesar $77,8 \%$, aspek kejelasan diperoleh persentase sebesar $81,5 \%$, aspek kemenarikan diperoleh persentase sebesar $80 \%$, dan aspek kemudahan diperoleh persentase sebesar $75 \%$. Nilai total dari keseluruhan aspek yang diperoleh dari ahli kepelatihan sebesar $78,6 \%$. Hasil tersebut menunjukkan bahwa produk termasuk dalam kategori baik dan layak untuk digunakan.

Data kualitatif yang diperoleh pada evaluasi ahli kepelatihan berupa saran-saran terhadap produk antara lain: (1) penambahan identitas jurusan, identitas pengembang, dan tahun pembuatan produk; (2) pemberian judul pada produk pengembangan; (3) pengurangan durasi tampilan 
video permainan NBA; (4) pemberian penjelasan berupa tulisan untuk setiap materi; (5) penulisan pada credit text tidak rapi.

Data kedua, merupakan data kuantitatif berupa hasil pengisian instrumen evaluasi ahli permainan bolabasket terkait produk pengembangan model latihan zone defense berdasarkan komponen produk terhadap aspek ketepatan diperoleh persentase sebesar $88,9 \%$, aspek kejelasan diperoleh persentase sebesar $75 \%$, aspek kemenarikan diperoleh persentase sebesar $75 \%$, dan aspek kemudahan diperoleh persentase sebesar $87,5 \%$. Nilai total dari keseluruhan aspek yang diperoleh dari ahli permainan bolabasket sebesar $81,6 \%$. Hasil tersebut menunjukkan bahwa produk termasuk dalam kategori baik sekali dan layak untuk digunakan.

Data kualitatif yang diperoleh pada evaluasi ahli permainan bolabasket berupa saran-saran terhadap produk antara lain: (1) pemberian penjelasan gerakan pada setiap materi; (2) pemberian arah gerakan khususnya pada model drill moving defense; (3) durasi tampilan video pada setiap materi tidak terlalu panjang dan tidak terlalu pendek.

Data ketiga, merupakan data kuantitatif berupa hasil pengisian instrumen evaluasi ahli pelatih terkait produk pengembangan model latihan zone defense berdasarkan komponen produk terhadap aspek ketepatan diperoleh persentase sebesar $97,2 \%$, aspek kejelasan diperoleh persentase sebesar $84,8 \%$, aspek kemenarikan diperoleh persentase sebesar $81,2 \%$, dan aspek kemudahan diperoleh persentase sebesar $87,5 \%$. Nilai total dari keseluruhan aspek yang diperoleh dari ahli pelatih sebesar $87,7 \%$. Hasil tersebut menunjukkan bahwa produk termasuk dalam kategori baik sekali dan layak untuk digunakan.

Data kualitatif yang diperoleh pada evaluasi ahli pelatih berupa saran-saran terhadap produk yaitu penambahan gambar slow motion pada setiap materi model latihan.

Data keempat, merupakan data kuantitatif berupa hasil pengisian instrumen evaluasi ahli manajemen ekstrakurikuler terkait produk pengembangan model latihan zone defense berdasarkan komponen produk terhadap aspek ketepatan diperoleh persentase sebesar $97,2 \%$, aspek kejelasan diperoleh persentase sebesar $81,5 \%$, aspek kemenarikan diperoleh persentase sebesar $78,7 \%$, dan aspek kemudahan diperoleh persentase sebesar $87,5 \%$. Nilai total dari keseluruhan aspek yang diperoleh dari ahli manajemen ekstrakurikuler sebesar $86,2 \%$. Hasil tersebut menunjukkan bahwa produk termasuk dalam kategori baik sekali dan layak untuk digunakan.

Data kualitatif yang diperoleh pada evaluasi ahli manajemen ekstrakurikuler berupa saran-saran terhadap produk antara lain: (1) penambahan tampilan judul dan identitas pengembang; (2) pengurangan durasi tampilan video permainan NBA.

Data kelima, merupakan data kuantitatif berupa hasil pengisian instrumen evaluasi ahli media terkait produk pengembangan model latihan zone defense berdasarkan komponen produk terhadap aspek kejelasan diperoleh persentase sebesar $81 \%$, aspek kemenarikan diperoleh persentase sebesar $77,7 \%$, dan aspek ketepatan diperoleh persentase sebesar $83,3 \%$. Nilai total dari keseluruhan aspek yang diperoleh dari ahli media sebesar $80,7 \%$. Hasil tersebut menunjukkan bahwa produk termasuk dalam kategori baik sekali dan layak untuk digunakan.

Data kualitatif yang diperoleh pada evaluasi ahli media berupa saran-saran terhadap produk antara lain: (1) pengurangan durasi tampilan video permainan NBA dan pemberian keterangan/judul tampilan video permainan NBA tersebut; (2) kejelasan warna tulisan; (3) pemberian tanda panah sebagai arah pergerakan dan fokus pergerakan; (4) pada setiap tampilan materi diberikan gambar secara individu, gambar slow motion, dan gambar secara keseluruhan; (5) penambahan slide untuk menjelaskan langkah kegiatan sebelum masuk pada tampilan video materi model latihan.

Data keenam, merupakan data kuantitatif berupa hasil pengisian instrumen uji coba produk kelompok kecil terkait produk pengembangan model latihan zone defense berdasarkan komponen produk terhadap aspek kejelasan diperoleh persentase sebesar $75,5 \%$, aspek kemenarikan diperoleh persentase sebesar $72,8 \%$, dan aspek kegunaan diperoleh persentase sebesar $75 \%$. Nilai total dari keseluruhan aspek yang 
Ratna Nathania N U, Pengembangan Model Latihan Zone Defense Menggunakan Video Pada Kegiatan Ekstrakurikuler Bolabasket di Charis National Academy Malang

diperoleh dari hasil uji coba produk kelompok kecil sebesar $74,5 \%$. Hasil tersebut menunjukkan bahwa produk termasuk dalam kategori baik dan layak untuk digunakan.

Data kualitatif yang diperoleh pada uji coba produk kelompok kecil berupa saransaran terhadap produk yaitu durasi pada saat penjelasan materi berupa tulisan terlalu pendek.

Data ketujuh, merupakan data kuantitatif berupa hasil pengisian instrumen uji coba produk kelompok besar terkait produk pengembangan model latihan zone defense berdasarkan komponen produk terhadap aspek kejelasan diperoleh persentase sebesar $77,5 \%$, aspek kemenarikan diperoleh persentase sebesar $80,7 \%$, dan aspek kegunaan diperoleh persentase sebesar $77,5 \%$. Nilai total dari keseluruhan aspek yang diperoleh dari hasil uji coba produk kelompok besar sebesar 78,6\%. Hasil tersebut menunjukkan bahwa produk termasuk dalam kategori baik dan layak untuk digu-nakan.

\section{PEMBAHASAN}

Produk hasil pengembangan yang telah dilaksanakan peneliti berupa model latihan zone defense yang dikemas dalam bentuk video. Pengembangan produk dalam penelitian ini dilakukan sebagai upaya untuk meningkatkan kemampuan kognitif dan meningkatkan keterampilan gerak (motorik) peserta kegiatan ekstrakurikuler dalam bermain bolabasket. Kemampuan motorik adalah suatu proses pembentukan suatu sistematika kognitif tentang gerak pada diri setiap peserta didik ataupun atlet yang kemudian diaplikasikan dalam psikomotorik, mulai dari tingkat keterampilan gerak yang sederhana hingga keterampilan gerak yang kompleks untuk mencapai otomatisasi gerak (Indahwati \& Tohirun, 2015:2). Sejalan dengan pendapat tersebut Dwijowinoto (1993:196) juga menyatakan bahwa penampilan gerak yang berhasil tergantung pada pencapaian kemampuan pada tiap-tiap ranah tingkah laku, bukan hanya kemampuan psikomotorik saja tetapi juga pada kemampuan kognitif dan afektif.

Pada ranah tingkah laku kognitif menuntut peserta kegiatan ekstrakurikuler menggunakan kemampuan intelektual untuk mempelajari peraturan, perkembangan stra- tegi permainan, merencanakan keterampilan gerak dan penggunaan informasi yang telah dipelajari secara efisien. Sedangkan pada ranah tingkah laku psikomotorik berkaitan dengan penerimaan informasi perseptual dan kemampuan untuk menerima respon gerak yang menghasilkan kesatuan gerak yang kompleks. Melalui kegiatan ekstrakurikuler, pelatih harus mampu menciptakan suasana pelatihan yang efektif, efisien, dan menarik minat peserta kegiatan ekstrakurikuler untuk dapat melakukan aktivitas gerak sesuai dengan kemampuannya dalam mencapai hasil latihan yang maksimal.

Keberadaan media sebagai alat komunikasi pembawa informasi dapat membantu dalam proses belajar/berlatih. Menurut Lamatenggo dan Uno (2010:121), media merupakan alat komunikasi yang digunakan untuk membawa suatu informasi dari suatu sumber kepada penerima. Penggunaan media pelatihan sangat penting dalam proses berlatih dan melatih. Pribadi (2011:88) menyatakan bahwa media pelatihan adalah alat yang digunakan untuk mendukung berlangsungnya proses pelatihan yang efektif, efisien, dan menarik.

Produk yang dikembangkan menggunakan video berdasarkan hasil studi pendahuluan dari peserta kegiatan ekstrakurikuler bolabasket dan pelatih yang membutuhkan model latihan zone defensel yang dikemas dalam bentuk video. Peneliti juga setuju dengan penggunaan video karena mengacu pada pendapat Arsyad dalam Dwiyogo (2008:1) bahwa media video adalah alat yang digunakan untuk menyalurkan atau menyampaikan pesan dengan tujuan pendidikan dan pelajaran. Menurut Pribadi (2011:97) media gambar bergerak atau motion pictures merupakan jenis media yang mampu memperlihatkan gambar bergerak yang terintegrasi dengan unsur suara. Media video dapat digolongkan ke dalam jenis media audio visual aids (AVA) yaitu jenis media yang selain mengandung unsur suara juga mengandung unsur gambar yang dapat ditonton (Rusman, 2013:218).

$\mathrm{Hal}$ ini juga sejalan dengan teori gaya belajar, dimana gaya belajar peserta terdiri atas gaya belajar visual dan gaya belajar audio (Hariyanto \& Suyono, 2011:149). Penggunaan video sangat menunjang keberhasilan dalam kegiatan belajar dan mengajar 
karena dapat memotivasi peserta didik dan meningkatkan kemampuan belajar melalui indra penglihatan dan indra pendengaran (Al-Haliq, dkk. 2014:22). Pemikiran dalam mengembangkan produk model latihan zone defense menggunakan video ini juga didasari oleh alasan pokok yang disampaikan oleh Irianto (2009:13) yang menyatakan bahwa variasi perlu diberikan karena model dan metode latihan yang monoton mengakibatkan kebosanan sehingga sasaran latihan tidak dapat dicapai, untuk itu perlu dirancang berbagai model dan metode latihan yang beranekaragam, dengan tetap mengacu pada sasaran latihan. Variasi latihan diberikan untuk mengatasi keadaan latihan yang monoton dan rasa bosan dalam latihan (Budiwanto, 2012:21). Prinsip variasi latihan dapat berupa variasi tempat, alat atau media yang digunakan dalam penyampaian materi tidak hanya dengan satu metode penyampaian saja.

Salah satu kemampuan video dalam proses pelatihan olahraga yaitu dapat menyajikan gerak lambat (slow motion) dan memberhentikan gambar yang sedang bergerak untuk dapat menganalisis bagian atau proses tertentu dari suatu gerak, video juga dapat membantu menjelaskan gerakan atau prosedur tertendu dengan lebih rinci (Lamatenggo \& Uno, 2010:135). Dapat disimpulkan bahwa media video merupakan salah satu media pelatihan yang efektif, efisien, dan menarik untuk dapat digunakan dalam pelatihan olahraga karena mengandung unsur suara dan gerak, dimana dengan menggunakan media video penonton dapat menganalisis setiap gerakan yang ditayangkan.

Pembuatan produk hasil penelitian dan pengembangan berupa model latihan zone defense menggunakan video ini telah melalui proses sistematis. Hasil analisis tinjauan para ahli, hasil uji coba kelompok kecil maupun besar dan penelitian yang berhubungan dengan produk yang dikembangkan peneliti sebagai berikut.

Berdasarkan hasil penilaian terkait pengembangan produk ini diperoleh hasil persentase kelayakan produk dari evaluasi ahli kepelatihan sebesar $78,6 \%$, ahli permainan bolabasket sebesar $81,6 \%$, ahli pelatih sebesar $87,7 \%$, ahli manajemen ekstrakurikuler sebesar $86,2 \%$, dan ahli media sebesar 80,7\%. Hasil penelitian keseluruhan dari 5 subjek ahli menyatakan bahwa produk termasuk dalam kategori baik dan layak untuk digunakan.

Penelitian olahraga terdahulu yang terkait dengan penggunaan media pembelajaran audio visual/video oleh Kusumawardhani pada tahun 2011 telah melakukan penelitian tentang penerapan media bantu pembelajaran audio visual untuk meningkatkan hasil belajar lay up bolabasket pada siswa kelas XA SMAN 1 Karanganom. Hasil penelitian tersebut menyatakan bahwa adanya peningkatan hasil belajar lay up shoot bolabasket akibat media bantu pembelajaran audio visual sebesar $32,50 \%$. Pada tahun 2012, Adyrama juga telah melakukan penelitian tentang penerapan electronic learning melalui media audio visual terhadap hasil shooting three point dalam olahraga bolabasket. Penelitian tersebut menunjukkan bahwa melalui penerapan pembelajaran electronic dengan media audio visual memberikan rata-rata peningkatan yang positif terhadap siswa kelompok eksperimen sebesar 5 poin dan siswa kelompok kontrol sebesar 3 poin terhadap hasil belajar shooting three point.

Berdasarkan penelitian olahraga terdahulu yang terkait dengan penelitian dan pengembangan ini maka dapat disimpulkan bahwa media audio visual atau video merupakan salah satu media pembelajaran yang baik digunakan dalam proses belajar mengajar terutama untuk mempelajari suatu keterampilan gerak (motorik) tertentu.

Produk pengembangan model latihan zone defense yang dikemas dalam bentuk video ini telah divalidasi oleh subjek ahli dan diperoleh beberapa saran yang digunakan peneliti sebagai acuan untuk melakukan revisi terhadap produk awal pengembangan ini. Revisi produk penting dilakukan agar produk awal yang dikembangkan menjadi lebih sempurna dan menarik untuk digunakan oleh calon pengguna produk. Hal ini sejalan dengan pendapat Dwiyogo (2008:1) bahwa media pembelajaran yang menarik akan merangsang dan menstimulus pebelajar untuk lebih termotivasi dalam menyerap informasi tentang sesuatu. Pribadi (2011:101) juga menyatakan bahwa sebuah media yang dirancang dengan kreatif, umumnya akan meningkatkan daya tarik isi 
Ratna Nathania N U, Pengembangan Model Latihan Zone Defense Menggunakan Video Pada Kegiatan Ekstrakurikuler Bolabasket di Charis National Academy Malang

pesan atau informasi yang terdapat di dalamnya. Oleh karena itu, tahap revisi produk awal ini perlu dilakukan oleh peneliti.

Adapun revisi pertama terkait pengembangan model latihan zone defense yang dikemas dalam bentuk video ini yaitu tampilan judul dan identitas pengembang. Penambahan tampilan judul dan identitas peneliti guna menunjukkan kejelasan materi yang akan disampaikan dan hak pembuatan oleh pengembang. Revisi yang kedua yaitu tampilan video permainan NBA. Durasi tampilan video permainan NBA dibuat sesingkat mungkin dan diberikan keterangan untuk memperjelas gambaran secara luas tentang materi yang akan disampaikan. Hal ini sejalan dengan pendapat Jayanti (2015:24) bahwa beberapa jenis efek visual tertentu seperti penyingkatan atau perpanjangan waktu dilakukan untuk memperkokoh proses belajar maupun nilai hiburan dari penyajian tersebut.

Revisi yang ketiga yaitu penjelasan berupa tulisan dan arah pergerakan. Penambahan penjelasan berupa tulisan perlu ditambahkan untuk membantu penonton untuk dapat memahami tujuan dan langkah kegiatan pada setiap model latihan dan penambahan arah gerakan guna memperjelas arah pergerakan dan fokus pergerakan. Revisi ketiga ini diperkuat dengan penelitian yang telah dilakukan oleh Raharjo dalam Rusman,dkk. (2013: 65) menyatakan bahwa kita hanya dapat mengingat $20 \%$ dari apa yang kita dengar, namun dapat mengingat $50 \%$ dari apa yang dilihat dan didengar. Oleh karena itu penjelasan berupa suara dirasa kurang cukup untuk menyampaikan tujuan dan langkah kegiatan tiap model latihan, maka perlu ditambahkan penjelasan berupa tulisan dan arah pergerakan.

Revisi keempat yaitu penambahan gambar lambat (slow motion) pada tiap tampilan model latihan. Pada tiap tampilan model latihan ditayangkan gambar lambat (slow motion) untuk memberikan waktu kepada penonton untuk mengamati proses keterampilan gerak tertentu. Hal ini didukung oleh pendapat Pribadi (2011:98) yang menyatakan bahwa fasilitas yang ada pada video seperti halnya kemampuan untuk memperlambat gerak (slow motion) dan memberhentikan gambar yang sedang bergerak (freeze frame) dapat dipergunakan untuk menganalisis bagian atau proses tertentu dari suatu gerakan.

Selanjutnya pelaksanaan uji coba keseluruhan dilakukan pada subjek coba sebagai calon pengguna produk yang terdiri atas kelompok kecil dengan melibatkan 10 peserta kegiatan ekstrakurikuler bolabasket dan kelompok besar dengan melibatkan 30 peserta kegiatan ekstrakurikuler bolabasket di Charis National Academy Malang. Pemberian materi pada masing-masing subjek uji coba (kelompok kecil dan kelompok besar) sebanyak 12 kali pertemuan.

Berdasarkan hasil pembagian kuisioner yang dibagikan kepada 30 responden didapatkan penilaian akhir berupa data kuantitatif dan data kualitatif. Data kuantitatif yang didapatkan berupa nilai persentase kelayakan produk oleh kelompok kecil sebesar 74,5 dan kelompok besar sebesar $78,6 \%$. Hasil tersebut menunjukkan bahwa produk termasuk dalam kategori baik dan layak untuk digunakan. Selanjutnya, data kualitatif didapatkan dari uji coba keseluruhan berupa saran terkait dengan pengembangan produk awal video tentang model latihan zone defense bolabasket yaitu penambahan durasi tampilan penjelasan berupa tulisan pada setiap model latihan supaya penonton dapat memahami dengan seksama tujuan dan langkah kegiatan model latihan.

Salah satu media yang variatif dan interaktif adalah media dan bahan pelatihan yang dapat dilihat dan didengar yaitu media video atau audio visual. Menurut Rusman, dkk. (2013:173), 90\% hasil belajar seseorang diperoleh melalui indra pandang, dan hanya $5 \%$ diperoleh melalui indra dengar dan 5\% lagi dari indra yang lainnya.

Oleh karena itu media video dikatakan sebagai media pembelajaran yang variatif karena dapat menggabungkan unsur gerak dan suara sehingga menjadikan media video sebagai media interaktif. Pembelajaran atau pelatihan dengan video merupakan suatu kegiatan pembelajaran mandiri dimana peserta didik belajar dengan kecepatan masing-masing individu (Jayanti, 2015:25). Salah satu kelebihan video dalam proses belajar keterampilan gerak yaitu dengan menggunakan video dapat memperlambat gerak (slow motion) dan memberhentikan gambar yang sedang bergerak (freeze 
frame) untuk dapat menganalisis bagian atau menjelaskan gerakan atau prosedur tertentu dengan lebih rinci (Lamatenggo \& Uno, 2010:135).

Keunggulan produk ini sebagai salah satu alternatif media pelatihan yang layak digunakan oleh pelatih dan peserta kegiatan ekstrakurikuler bolabasket adalah sebagai berikut: (1) penyusunan materi model latihan zone defense disusun berdasarkan prinsip variasi latihan, yaitu menampilkan tingkat keterampilan gerak mulai dari gerak yang sederhana menuju gerak yang kompleks; (2) terdapat tampilan gambar video permainan NBA, gambar video materi latihan yang didalamnya terdapat tampilan gerak lambat (slow motion) dan terdapat penjelasan berupa tulisan dan suara penjelasan dan musik yang sesuai dengan isi materi untuk menarik minat peserta kegiatan ekstrakurikuler untuk mempelajarinya; (3) produk pengembangan ini dapat dijadikan sebagai salah satu alternatif media pelatihan, baik sebagai bahan pelatihan secara individu ataupun kelompok; (4) pemilihan media video untuk model latihan zone defense bolabasket ini sangat tepat dalam menunjukkan suatu proses keterampilan motorik.

Sukiyandari, dkk. (2012:170) menyatakan bahwa hal yang terpenting dalam proses belajar mandiri ialah peningkatan kemampuan dan keterampilan peserta didik dalam proses belajar tanpa bantuan orang lain untuk memahami isi pembelajaran yang dibaca dan dilihatnya melalui media video. Materi model latihan yang disusun berdasarkan prinsip variasi latihan yang dikemas dalam bentuk video ini diharapkan dapat membantu keberhasilan belajar gerak setiap invidu untuk mendapatkan hasil latihan yang optimal baik dalam peningkatan kemampuan berpikir (kognitif) dan keterampilan motorik.

Produk pengembangan model latihan zone defense yang dikemas dalam bentuk video juga masih memiliki beberapa keterbatasan yang perlu untuk dikembangkan lebih lanjut. Keterbatasan tersebut adalah topik yang dikembangkan dalam produk pengembangan ini terbatas pada model latihan zone defense pola 2-1-2 dan 1-2-2. Keterbatasan selanjutnya adalah tahapan uji coba penelitian masih terbatas pada uji coba kelompok kecil dan uji coba kelompok besar.

\section{KESIMPULAN}

Hasil penelitian dan pengembangan dapat disimpulkan sebagai berikut: (1) berdasarkan hasil hasil tinjauan/evaluasi para ahli bahwa produk pengembangan model latihan zone defense bolabasket menggunakan video ini dinyatakan memiliki kejelasan, kemenarikan, ketepatan, dan kemudahan untuk digunakan oleh peserta kegiatan ekstrakurikuler bolabasket di Charis National Academy Malang; (2) berdasarkan hasil tinjauan/evaluasi subjek coba sebagai calon pengguna produk bahwa produk pengembangan model latihan zone defense bolabasket menggunakan video ini dinyatakan memiliki kejelasan, kemenarikan, dan kegunaan bagi peserta kegiatan ekstrakurikuler bolabasket di Charis National Academy Malang.

\section{SARAN}

Berdasarkan uji kelayakan produk yang telah dilakukan melalui uji ahli dan subjek coba, maka produk pengembangan ini dapat dijadikan sebagai alternatif media pelatihan yang dapat digunakan pada kegiatan ekstrakurikuler bolabasket baik di sekolah maupun di tempat pelatihan olahraga sesuai dengan tujuan pengembangan dan karakteristik peserta kagiatan ekstrakurikuler.

Saran pengembangan produk lebih lanjut sebagai berikut: (1) pengembang selanjutnya dapat menambahkan model latihan zone defense yang lainnya untuk melengkapi isi dari produk pengembangan ini; (2) dapat dilakukan uji efektivitas terhadap produk pengembangan ini, karena hasil pengembangan ini masih terbatas sampai tersusunnya sebuah produk.

\section{DAFTAR RUJUKAN}

Ahmadi,Nuril 2007. Permainan Bola Basket. Surakarta: era intermedia. 
Ratna Nathania N U, Pengembangan Model Latihan Zone Defense Menggunakan Video Pada Kegiatan

Al-Haliq, dkk. 2014. The Effect of Using Video on Developing Physical Fitness of Physical Education Students at the Hashemite University. Asian Social Science, (Online), $10 \quad$ (1): 21-27, (http://www.ccsenet.org/journal/inde x.php/ass/article/download/33114/19 168.), diakses 9 Juni 2016

Ardhana, W. 2002. Metodologi Penelitian Pengembangan Bidang Pendidikan dan Pembelajaran, Makalah disajikan dalam Lokakarya Jurusan IImu Keolahragaan UM, Malang 2224 Maret 2002.

Bompa,Tudor. \& Haff, Greg. 2009. Periodization:Theory and Methodology of Training. USA: Human kinetics.

Borg, W.R. \& Gall, M.D. 1983. Educational Research An Introduction. Fourth Edition. New York: Longman.

Budiwanto, Setyo. 2011. Metodologi Kepelatihan Olahraga. Malang: UM Press.

Budiwanto, Setyo. 2012. Metodologi Latihan Olahraga. Malang: UM Press.

Dwijowinoto, Kasio. 1993. Dasar-dasar IImiah Kepelatihan.Semarang: IKIP Semarang Press

Dwiyogo, W. D. 2008. Aplikasi Teknologi Pembelajaran Media Pembelajaran Penjas \& Olahraga. Malang: Universitas Negeri Malang.

Gilang, M. 2007. Pendidikan Jasmani Olahraga dan Kesehatan SMA Kelas $X I$. Jakarta: Ganeca

Hariyanto \& Suyono. 2011. Belajar dan Pembelajaran. Bandung: PT. Remaja Rosdakarya Offset

Husdarta, J.S \& Maryani, E. 2010. Praktis Belajar Pendidikan Jasmani, Olahraga, dan Kesehatan untuk
Kelas XII SMA/MA/SMK.

Kementerian Pendidikan Nasional: Visindo Media Persada

Indahwati, Nanik \& Tohirun, Alma'i. 2015. Perbandingan Kemampuan Motorik Siswa Yang Mengikuti Ekstrakurikuler Olahraga dan Non Olahraga di SDN 1 Rengel, Kab. Tuban Tahun Ajaran 2014-2015. Jurnal Pendidikan Olahraga dan Kesehatan, (Online), 3 (3): 640-646, (http://ejournal.unesa.ac.id/article/178 20/68/article.pdf), diakses 10 Juni 2016.

Irianto, Pekik Djoko dkk. 2009. Materi Pelatihan Kondisi Fisik Dasar. Jakarta: ASDEP Pengembangan Tenaga \& Pembina Keolahragaan.

Jayanti. 2015. Pengembangan Model Video Pembelajaran Passing Dalam Permainan Bola Voli Pada Siswa Kelas XI SMAN 15 Semarang Kota Semarang Tahun Pelajaran 2014/2015. Skripsi tidak diterbitkan. Semarang: Universitas Negeri Semarang.

Kompri. 2015. Manajemen Pendidikan. Yogyakarta: Ar-Ruzz Media.

Kusumawardhani, Dewi. P. 2012. Penerapan Media Bantu Pembelajaran Audio Visual Untuk Meningkatkan Hasil Belajar Lay Up Shoot Bola Basket Pada Siswa Kelas XA SMAN 1 Karanganom Kabupaten Klaten Tahun Pelajaran 2011/2012. Skripsi tidak diterbitkan. Klaten

Lamatenggo, Nina \& Uno, H.B. 2010. Teknologi Komunikasi dan Informasi Pembelajaran. Jakarta: Bumi Aksara

M. Kukuh S. 2008. Pengembangan Model Latihan Zone Defense/Bertahan dalam Kegiatan Ekstrakurikuler Bolabasket di SMA Islam Kepanjen Kabupaten Malang. Skripsi tidak diterbitkan. Malang: FIK UM.

Metalian, Alfredo Jerry M. 2010. Pengembangan Model Latihan Man 
to Man Defense Bolabasket Menggunakan Modifikasi Permainan Gobak Sodor di Ekstrakurikuler SMP Laboratorium UM Malang. Skripsi tidak diterbitkan. Malang: FIK UM.

Mukhadis, A. 2013. Evaluasi Program Pembelajaran Bidang Teknologi. Malang: Bayumedia

Mukholid, Agus. 2007. Pendidikan Jasmani Olahraga dan Kesehatan SMA kelas XII. PT. Ghalia Indonesia Printing: Yudhistira

Oliver, John. 2007. Dasar-dasar Bola Basket. Bandung: Pakar Raya

Peraturan Menteri Pendidikan dan Kebudayaan Republik Indonesia Nomor 62 Tahun 2014 Tentang Kegiatan Ekstrakurikuler Pada Pendidikan Dasar dan Pendidikan Menengah.

(Online),(sdm.data.kemendikbud.go.i d/SNP/dokumen/kur/permennomor62 tahun2014ttgkeg.eks.pdf), diakses 14 November 2015

Pujianto, Agus. 2014. Persepsi Guru Pendidikan Jasmani Terhadap Model Teaching Gamses For Understanding (TGFU). Journal of Physical Education, Health dan Sport, (Online), $\quad 1 \quad$ (2):7985, (http://journal.unnes.ac.id/nju/inde x.php/ipehs), diakses 23 Mei 2016

Pribadi, Benny A. 2011. Model Assure untuk Mendesain Pembelajaran Sukses. Jakarta: PT. Dian Rakyat.

Prihatin, Eka. 2011. Manajemen Peserta Didik. Bandung: Alfabeta.

Rusman, dkk. 2013. Pembelajaran Berbasis Teknologi Infromasi dan Komunikasi. Jakarta: PT. RajaGrafindo Persada

Sukadiyanto. 2011. Pengantar Teori dan Metodologi Melatih Fisik. Bandung: CV. Lubuk Agung.
Sukiyandari, Liska, dkk. 2012. Multimedia Bola Basket Untuk Pembelajaran Pendidikan Jasmani Olahraga dan Kesehatan di SMA. Journal of Physical Education and Sports, (Online), 1 (2): 167-173,

(http://journal.unnes.ac.id/sju/index.p hp/jpes/article/download/81

2/838), diakses 23 Mei 2016

Zheng, Aihua, dkk. 2010. Structurebased Extraction in Basketball Zone Defense Strategies. Internasional Journal of Computer Science and Aplications, (Online), 7 (3): 18-32, (www.tmrfindia.org), diakses 18 Juli 2016 